Canadian University Music Review

Revue de musique des universités canadiennes

\author{
Shane K. Bernard. Swamp Pop: Cajun and Creole Rhythm and \\ Blues. American Made Music Series. Jackson: University of \\ Mississippi Press, 1996. CD included, xiii, 264 pp. ISBN \\ 0-87805-875-3 (hardcover)
}

\title{
Ken McLeod
}

Volume 18, numéro 2, 1998

URI : https://id.erudit.org/iderudit/1014665ar

DOI : https://doi.org/10.7202/1014665ar

Aller au sommaire du numéro

\section{Éditeur(s)}

Canadian University Music Society / Société de musique des universités canadiennes

ISSN

0710-0353 (imprimé)

2291-2436 (numérique)

Découvrir la revue

Citer ce compte rendu

McLeod, K. (1998). Compte rendu de [Shane K. Bernard. Swamp Pop: Cajun and Creole Rhythm and Blues. American Made Music Series. Jackson: University of Mississippi Press, 1996. CD included, xiii, 264 pp. ISBN 0-87805-875-3

(hardcover)]. Canadian University Music Review / Revue de musique des

universités canadiennes, 18(2), 124-127. https://doi.org/10.7202/1014665ar

All Rights Reserved (C Canadian University Music Society / Société de musique des universités canadiennes, 1998
Ce document est protégé par la loi sur le droit d'auteur. L'utilisation des services d'Érudit (y compris la reproduction) est assujettie à sa politique d'utilisation que vous pouvez consulter en ligne.

https://apropos.erudit.org/fr/usagers/politique-dutilisation/ 
Shane K. Bernard. Swamp Pop: Cajun and Creole Rhythm and Blues. American Made Music Series. Jackson: University of Mississippi Press, 1996. CD included. xiii, 264 pp. ISBN 0-87805-875-3 (hardcover).

Though it has remained almost completely unrecognized by those outside of its immediate practitioners, Louisiana swamp pop was at the heart of much of the 1950s and 1960s rock and roll. Many swamp-pop tunes such as Phil Phillip's "Sea of Love," Joe Barry's "I'm a Fool to Care," Johnny Preston's "Runnin' Bear," and Bobby Charles's "Later Alligator" made a significant impact on the rock charts in their own right and were extremely influential on the styles of many other top acts of the day including Fats Domino, "The Big Bopper," Elvis, and even the Beatles.

A distinct sister genre of the more popular Cajun and zydeco music, swamp pop arose as teenage Cajuns and Creoles discarded the violins and accordions which were central to the music of their French-Acadian heritage, and adopted electric guitars, saxophones, pianos, and modern trap drum sets, the common tools of the emerging styles of rhythm and blues and rock and roll then being disseminated from larger urban centers such as New Orleans. Drawing on more than fifty interviews with swamp-pop musicians in south Louisiana and southeast Texas, Shane K. Bernard's Swamp Pop explores the history, definition, and living tradition of this form which interweaves elements of country and western, rhythm and blues, rock and roll, with traditional elements of rural Cajun and Creole heritage. The son of the influential swamp-pop musician Rod Bernard, Shane Bernard's work represents the first book entirely devoted to this overlooked genre and is an intelligent and sensitively written ethnomusicological survey of this hybrid form.

Surprisingly enough "swamp pop" was a term coined by English pop music author Bill Millar in the late 1960s, the result of English enthusiasm for the imported sound shortly after its American inception. "Swamp pop" has since come to be regarded as Louisiana's third major indigenous genre in addition to the traditional forms of Cajun and black Creole music. Unlike Cajun and zydeco which divide along racial lines and use folk instrumentation and francophone lyrics, swamp pop is a biracial genre which employs primarily English lyrics and 1950s rhythm and blues instrumentation. It represented "a natural outcome of the colliding cultural elements-Cajun and Creole, black and white, French and English, rural and urban, folk and mainstream-that coalesced in the prairies of southwestern Louisiana" (p. 8). As Bernard explains, swamp pop "is typified by highly emotional vocals, simple, unaffected (and occasionally bilingual) lyrics, tripleting honkey-tonk pianos, bellowing sax sections, and a strong rhythm and blues backbeat" (p. 5). Faster upbeat compositions often employ a Cajun-Creole two-step rhythm while slow, usually melancholic ballads are marked by a "heavy triplety feel, undulating bass lines, climactic turnarounds, and dramatic breaks" (p. 6). Reflecting its hybrid mixture of classic rock and roll, rhythm and blues, country, and Cajun and Creole styles, the music is simple, concentrating on tonic, subdominant, and dominant progressions structured in a variety of balanced bar forms, and 
with catchy repetitive vocal melodies supplemented by accordion, sax, or guitar solos. Despite the simplicity of the musical materials they are used in an endless variety of ways. Perhaps above all else, it must be remembered that this is dance music.

Bernard begins his book with a brief account of the Acadian settlement in Louisiana and explains the differences between Creole (usually Catholic, francophone Louisianians of African descent) and Cajun (usually white French-speaking Acadians and various ethnic groups dominated by Acadian culture) cultures in the region. He expands this sociological history into a survey of the various musical traditions of these cultures and proceeds to delineate the existence of the distinct yet hybrid form of swamp-pop music which arouse out of the mixture of these two cultural groups. Such ethnic juxtapositions are often fraught with tensions and a constant underlying theme to Bernard's work is the variety of social pressures which swamp-pop artists faced during the late 1950s and early 1960s. Racial violence and discrimination faced many of the black Creole swamp poppers. Huey "Cookie" Thierry (lead singer for Cookie and the Cupcakes), for example, was subjected to constant harassment from white Cajun males for fraternizing with white women admirers. Language barriers and prejudices were also influential elements as many artists were forced to abandon their traditional French lyrics in favour of English in order to conform to commercial pressures. In this and other cultural details Bernard's study makes for an interesting comparison with the fate of Francophone pop music in Canada during the same period.

One of the most interesting chapters in the book, "The Future of Swamp Pop" delves into the contemporary practice of this music and its considerable historical influence on a variety of well-known artists. Though largely a regional genre on the verge of dying out, swamp pop continues to be cultivated in the clubs and bars and music festivals of South Louisiana. As described by Bernard the "golden age of swamp pop stretched from 1958-1963," a period which, along with many other musical trends in North America, ended with the Beatles and the ensuing British invasion (p. 99). These external factors, in combination with the swamp poppers growing older and retiring to raise families and to pursue more stable non-musical careers, saw swamp pop wane towards the end of the 1960s. In 1975, however, Freddy Fender reached the national charts with his renditions of two swamp-pop classics "Wasted Days and Wasted Nights" and "Before the Next Teardrop Falls."

Despite its own lack of popular recognition, swamp pop nonetheless had a considerable impact on other influential artists and musical genres. In 1955 Bill Haley and His Comets issued their well-known cover of "Later Alligator," a swamp-pop tune originally composed by legendary swamp popper Bobby Charles. One of the most notable figures to be influenced by the sound was Fats Domino who recorded songs with distinct swamp-pop influences such as "Walkin to New Orleans" (1960) and "Before I Grow Too Old" (1960), also composed by Bobby Charles. Domino went on to record at least seven other tunes composed by another influential swamp popper Jimmy Donley. More recently Donnie and Marie Osmond, at the height of their success in the mid 
1970s, had an international hit with their cover of Dale Houston and Grace Brossard's swamp-pop classic "I'm Leaving It Up to You" a song which became the title track of the Osmonds' album. Perhaps the most intriguing example of the influence of swamp pop, however, is "Oh Darling!" a LennonMcCartney song from the Beatles' 1969 Abbey Road album. This song is taken by Bernard to be "typical of the sound, the rhythm patterns, the arrangements" of south Louisiana and to sound "incredibly like swamp pop and not quite like New Orleans rhythm and blues" (pp. 106, 107). Bernard presents some secondary evidence of the Beatles' acquaintance with the swamp-pop genre but there is little supporting evidence of direct contact or influence. Nonetheless the song, ironically, became so popular in South Louisiana that it inspired numerous cover versions by actual swamp-pop artists. Though "Oh Darling" appears to be a curious manifestation of the "taking coals to Newcastle" adage, a more concrete example of swamp pop's influence on English pop was manifest in 1984 when former Led Zeppelin lead singer Robert Plant covered Phil Phillips's swamp-pop classic "Sea of Love" with his new band the Honeydrippers.

Of course swamp pop was also influential on the development of popular Cajun artists such as Wayne Toups, Zachary Richard, Bruce Daigrepont, and the band Mamou. Unfortunately record companies, even independent Louisiana record companies, have largely failed to support the genre. Likewise swamp pop receives little radio play and even many folk-music festivals have shied away from swamp pop in favour of the more commercially viable forms of Cajun and zydeco music. Despite this lack of institutional assistance, artists such as Rod Bernard and Tommy McLain continue to perform in the traditional style at local nightclubs.

Perhaps the most outstanding feature of Bernard's book is his first-hand interviews with numerous swamp-pop pioneers. Most of the last half of the book is devoted to these personal "case studies" of the most influential swamp-pop artists including Huey "Cookie" Thierry, King Karl, Guitar Gable, Bobby Charles, Warren Storm, Johnnie Allan, Gene Terry, Joe Barry, and Benny Graeff. The studies proceed from contemporary interviews and focus primarily on autobiographical details and personal memories of the circumstances surrounding various songs and recording sessions. These "case studies" are wonderful portraits of these artists, but they provide little in the way of critical analysis of their music. Likewise, little effort is made to distinguish the musical style and contributions of each of the artists from each other. Nonetheless they provide an intimate, if somewhat romantically nostalgic, portrait of the swamp-pop scene as it existed in the 1950s and 1960s and as it exists today.

If, after reading Bernard's book, you have any lingering doubts as to the importance of this music or its place as a distinct indigenous Louisiana genre, they will be removed by listening to the accompanying CD sampler. The CD includes fourteen of the most influential swamp-pop songs recorded by the original artists including "Matilda" and "Sea of Love" by Cookie and the Cupcakes, "This Should Go On Forever" by Rod Bernard, and "Promised 
Land" by Johnnie Allan. The performances span a variety of swamp-pop styles and eras and include examples of the faster swamp-pop rockers such as "Opelousas Sostan" by Rufus Jagneaux and the slower ballad forms such as Johnnie Allan's "Lonely Days and Lonely Nights." This music, naive in its technical simplicity, nonetheless expresses a wide range of emotions and projects an indefinable, yet ineffable, rock and roll spirit. Though the recordings are, in some cases, almost forty years old they maintain a refreshing vitality - a testimony both to the original spirit of the music and the fact that it has received very little commercial exposure over the ensuing decades. The $\mathrm{CD}$ is a wonderful companion to the book and brings Bernard's writing and his case studies to life. It is both an invaluable aural introduction to, and documentation of, this nearly extinct musical genre.

Bernard's goal in writing this book is to increase the general awareness and appreciation of the genre of swamp-pop music and to voice his concerns "about whether it could survive and about how it was perceived" (p. 5). Consequently the writing contains little in the way of detailed musical or cultural analysis or criticism but a wealth of first-hand descriptions and accounts of the music and its conception. Accordingly, Bernard treats his subject with the warmth and affection of someone born into the swamp-pop tradition. Indeed the largest part of his work is drawn from the author's own interviews with the original swamp-pop artists. His message regarding the importance of this regional popular music style and its impending demise is well taken and the book provides a comprehensive survey of the genre and its artists and nicely imparts the complex flavours of the swamp-pop experience. As such it represents a unique and long overdue study of an important yet overlooked musical genre. Indeed, if only for the obvious linguistic and cultural parallels, it is a work worth reading by anyone interested in the pop music history of our own French-Canadian heritage.

Ken McLeod

Mark DeBellis. Music and Conceptualization. Cambridge: Cambridge University Press, 1995. viii, 163 pp. ISBN 0-521-40331-6 (hardcover).

Mark DeBellis's new book, Music and Conceptualization, offers a formal philosophical analysis of the following thesis: "a trained music listeners hear music differently from 'ordinary listeners." DeBellis begins with an assumption:

a trained [music] listener's perceptual concepts are typically integrated with theories of music and analytic frameworks. ... [A]n ordinary listener's musical hearing [is typically not integrated this way and therefore] is strongly nonconceptual" (p. 7, italics mine).

So, for DeBellis, "training" is the listener's ability to apply music-theoretic concepts to what s/he hears perceptually: "the semantic properties of "hears ... as a dominant' depend on those of 'is a dominant,' and our understanding of 